\title{
STABILITY STATISTICS OF SOME SESAME GENOTYPES
}

(Received: 21.1.2015)

\author{
By \\ F. Sh. Sedeck and S. A. Farag \\ Oil Crops Department, Field Crops Research Institute, and *Centeral Laboratory for Design \& \\ Statistical Analysis Research, Agricultureal Research Center, Giza, Egypt.
}

\begin{abstract}
The present study aimed to estimate different stability statistics to evaluate the behavior of some sesame genotypes grown under12 diverse environments in four successive summer seasons of 2011, 2012, 2013 and 2014. Forteen sesame genotypes, in addition to one check cultivar, were planted in three locations of upper Egypt, [Shandaweel (Sohag), El-Mataana (Luxor) and Mallawi (Elmenia)]. The design used was randomized complete blocks design with three replications as well as using four stability methods [Eberhart and Russell (1966), Tai 1971, shukla (1972) and Kang and Magari (1995)]. The studied characters were plant height, length of fruiting zone, number of capsules/ plant,1000 seed weight, seed weight/plant (g) and seed yield (ardeb/fed). Results indicated that the genotypes significantly differed for all the studied traits. Also genotype $\mathrm{x}$ environment $(\mathrm{GxE})$ interaction was highly significant for all the studied traits. Genotype No.12 (N.A.653) was phenotypically and genotypically stable using the three stability procedures of Eberhart and Russell (1966), Tai (1971), and Kang and Magari (1995) for plant height. Considering fruiting zone length, genotype No. 4 (B21) was stable using the three stability methods while the genotype No. 6 (N.A. 463) was stable for number of capsules/ plant using the same three methods of stability. Concerning 1000 seed weight, genotype No. 6 (N.A. 463) was stable by using Shukla (1972) and Kang and Magari (1995) methods of stability. The results revealed that genotype No. 5 (Hybrid167), No. 10 (N.A.542) and No.12 (N.A.653) for seed weight/plant, and genotypesNo.4 (B21), No.5 (Hybrid167) and No.10 (N.A.542) for seed yield (ardab/fed), were stable by using two methods of stability Eberhart and Russell, 1966 and Kang and Magari, 1995 . In light of the current results, it can be concluded that genotype No. 5 (Hybrid167) may be recommended to be released as a commercial stable genotype for seed weight/plant (g) and seed yield (ardab/fed) by using two methods of stability (Eberhart and Russell (1966) and Kang and Magari (1995), and incorporated to be as a breeding stock in any future breeding program.
\end{abstract}

Key words: sesame, Gx E interaction, stability statistics and yield components.

\section{INTRODUCTION}

Sesame (Sesamum indicum L.) is an important oil seed crop world- wide and its yield is of a high quality. It is an edible crop that contains odorless oil. Besides, it serves as a good source of protein and fat for humans and livestock. The crop is grown under a wide range of environments, which probably affects its performance. The variability among locations, seasonal fluctuations and their interaction highly influence the performance of genotypes in relation to yield potential. Identification of stable genotypes across a wide range of environments is a challenging task to breeders. Yield is still generally low and vary from one area to another due to lack of improved and certified seeds.
Genotype by environment ( $\mathrm{G}$ x E) interaction and stability of sesame were determined by several investigators. Kumar and Kumar (2004) studied the genotypic and phenotypic stabilities for seed yield and its components in sesame. They revealed that sufficient $G \times \mathrm{E}$ interaction was exhibited for all the characters of interest. In Pakistan, Sarwar et al. (2010) indicated that highly significant differences were observed among genotypes, environments and their interaction $(\mathrm{G} \times \mathrm{E})$.

Eberhart and Russell (1966) reported that regression of the mean performance of a genotype on an environmental index and the deviation from regression are two parameters to measure phenotypic stability of the tested 
genotypes. Another statistical procedure was described by Tai (1971), who suggested partitioning the genotypes $\mathrm{x}$ environments interaction into two components namely: $\alpha$ statistic that measures the linear response to environment effects and $\lambda$ that measures the deviation from linear response in terms of magnitude of error variance.

The methods that provide a stability variance parameter assignable to each genotype should be useful to the breeder. Shukla (1972) developed an unbiased estimate of stability variance of the genotype $\left(\sigma^{2}\right)$ and also a criterion for testing the significance of $\sigma_{i}^{2}$ to determine whether or not a genotype was stable. The stability variance method has been evaluated by Eagles and Frey (1977) to select oat (Avena sativa) cultivars. This method can be extended to use a covariate to remove its linear effect from GE interaction. The remainder variance of GE interaction can be assigned to each genotype $\left(S^{2}{ }_{i}\right)$ and the significance of each component tested. Kang and Miller (1984), and Kang and Magari (1995) depending only on Shukla (1972) proposed an integrated yield and stability of performance statistics $\left(\mathrm{Ys}_{i}\right)$ for simultaneous selection for yield and stability. Therefore, the present work was conducted to identify 1) the genotypes with good performance across all environments, 2) the responses of such traits to different cultural environments with the objective of determining traits associated with more stable varieties, and 3 ) the reliability of some stability statistics for evaluating 15 genotypes of sesame.

\section{MATERIALS AND METHODS}

\subsection{Experimental design and plant materials}

Fourteen promising genotypes of sesame and one check commercial cultivar (Shandaweel3) were used. The details of the tested genotypes are described in Table (1). In four successive summer seasons of 2011, 2012, 2013 and 2014, 14 sesame genotypes, in addition to one check cultivar, were planted at each of three locations, (Shandaweel, El-Mtaana and Mallawi). In each of the twelve environments (the combination of 4 years $\times 3$ locations), each genotype was planted in a randomized complete block design (RCBD) with three replications. Sowing was done by hand in plots of 5 rows each of $4 \mathrm{~m}$ long and spaced 50 and $20 \mathrm{~cm}$ between rows and plants in the same row, respectively. Individual plot size was $4 \times 2.5 \mathrm{~m}=10 \mathrm{~m}^{2}$. In all experiments, weeds were controlled by hand as needed. All other treatments were conducted according to recommendations.

\subsection{Variables recorded}

At harvest, a random sample of 10 plants from each plot was taken to measure plant height $(\mathrm{cm})$, fruiting zone length $(\mathrm{cm})$, number of capsules per plant, 1000- seed weight ( $\mathrm{g}$ ), seed yield per plant (g) and seed yield per feddan. To reduce border effects, data were recorded from the three central rows of each plot. The seed yield of each plot was recorded in $(\mathrm{Kg})$, which was adjusted to calculate yield in ardab per feddan $($ ardab $=120 \mathrm{~kg}$ and one feddan $=4200$ $\mathrm{m}^{2}$ )

\subsection{Statistical and stability analysis \\ 2.3.1. Analysis of variance}

Regular analysis of variance of RCBD as outlined by Gomez and Gomez (1984) was applied on each individual environment. Bartlett's test of homogeneity was adopted indicating no statistical evidence for heterogeneity. Thus, combined analysis of variance for the fifteen studied genotypes across twelve environments was worked out.

\subsubsection{Stability analysis}

Four stability methods were performed, namely,(Eberhart and Russell (1966), (Tai, 1971), stability variance (Shukla 1972) and yield stability statistic (Kang and Magari 1995), for differentiating the studied sesame genotypes, and to use the available information from these estimates for obtaining stable genotypes to be released as experimental lines to be incorporated in breeding programs for stable high yielding potential cultivars. Stability of the genotypes across environments was assessed by computing mean performance across environments $\left(\mathrm{x}_{\mathrm{i}}\right)$.

\subsubsection{Phenotypic stability}

In the analysis of phenotypic stability of Eberhart and Rusell (1966), the performance of each individual genotype is regressed on an environmental index (deviation of the mean yield at the environment from the overall mean yield of all environments). This analysis provides the linear regression coefficient, $b_{i}$, (performance response index and the deviation from regression mean square, $\mathrm{S}^{2} \mathrm{~d}_{\mathrm{i}}$ (stability index). 
Table (1): The details of the studied sesame genotypes

\begin{tabular}{|c|c|c|c|c|c|c|c|}
\hline \multirow{2}{*}{ No. } & Genotypes & \multirow{2}{*}{ Origin } & $\begin{array}{c}\text { Mo. of capsules } \\
\text { / leaf axel }\end{array}$ & $\begin{array}{c}\text { Branching } \\
\text { habit }\end{array}$ & $\begin{array}{c}\text { Seed } \\
\text { color }\end{array}$ & Shattering & $\begin{array}{c}\text { Tolerant for } \\
\text { welting disease }\end{array}$ \\
\hline 1 & Hybrid133 Family4 & Egypt & Three & Non branched & Brown & Indehiscent & Tolerant \\
\hline 2 & Hybrid16 Family2 & Egypt & Three & Non branched & Brown & Dehiscent & Susceptible \\
\hline 3 & Hybrid116 Family5 & Egypt & Single & Non branched & Brown & Dehiscent & Susceptible \\
\hline 4 & B21 & Egypt & Single & Non branched & Brown & Indehiscent & Tolerant \\
\hline 5 & Hybrid167 & Egypt & Single & Branched & White & Dehiscent & Tolerant \\
\hline 6 & N.A. 463 & U.S.A. & Single & Branched & White & Dehiscent & Tolerant \\
\hline 7 & Hybrid82 Family114-2 & Egypt & Single & Branched & Creamy & Indehiscent & Tolerant \\
\hline 8 & Hybrid102Family65-2 & Egypt & Single & Branched & Brown & Indehiscent & Tolerant \\
\hline 9 & N.A.504 & F.A.O & Three & Branched & White & Dehiscent & Tolerant \\
\hline 10 & N.A.542 & F.A.O & Three & Branched & White & Dehiscent & Tolerant \\
\hline 11 & N.A.545 & F.A.O & Three & Branched & Brown & Indehiscent & Tolerant \\
\hline 12 & N.A.653 & F.A.O & Three & Branched & Brown & Indehiscent & Tolerant \\
\hline 13 & Hybrid 108 Family5 & Egypt & Single & Non branched & Brown & Dehiscent & Susceptible \\
\hline 14 & Hybrid17 Family7 & Egypt & Single & Branched & White & Dehiscent & Susceptible \\
\hline 15 & Shandaweel3 & Local & Three & Non branched & White & Indehiscent & Tolerant \\
\hline
\end{tabular}

\subsubsection{Genotypic stability}

Concerning genotypic stability, genotype $\mathrm{x}$ environment interaction effect was partitioned into two statistics which were estimated for each genotype separately. The first statistic is $\alpha_{\mathrm{i}}$, that measures the linear response to environmental effects and the second is $\lambda_{i}$ that measures deviation from linear response in terms of magnitude of the error variance. Genotype of perfect stability would not change its performance from one environment to another. This is equivalent to stating that $\alpha=-1$ and $\lambda=1$. Because perfectly stable genotypes probably do not exist, plant breeders will have to be satisfied with obtainable levels of stability, i.e., average stability ( $\alpha=0$ and $\lambda=1$ ) will be as below average stability, however the values ( $\alpha<0$ and $\lambda=1)$ will be referred to as above average stability.

\subsubsection{Stability variance of Shukla's (1972)}

Stability variance was determined separately by calculating unbiased estimators of $\sigma_{i}^{2}$ and $s_{i}{ }^{2}$ and after considering the linear effect of environmental index, respectively. To remove the effect of the environmental index, $\mathrm{G} \times \mathrm{E}$ interaction, the sum of squares was divided into two components: heterogeneity due to linear effect of environmental index (measured as environment mean yield minus overall mean yield) and the residual or deviation variance components.

\subsubsection{Yield stability method}

The yield stability statistic $\left(\mathrm{Ys}_{i}\right)$ method developed by Kang and Magari (1995) depending on Shukla's method (1972) was used.
In this method, the degree of stability of higher performance via two statistics i.e $\sigma^{2}{ }_{i}$ and $\mathrm{Y}$, was confounded into one measure called $\mathrm{Ys}_{i}$. The various steps used in calculating the $\mathrm{Ys}_{i}$ statistic for the its genotype are as follows; (i) determining the contribution of each genotype to GE interaction by calculating $\sigma_{i}^{2}$, (ii) assigning ranks to genotypes from highest to lowest yield receiving the rank of 1; (iii) calculating protected LSD for mean yield comparisons; (iv) adjust yield rank according to LSD; (v) determine significance of $\sigma_{\mathrm{i}}^{2}$ using an approximate $\mathrm{F}-$ test; (vi)assign stability rating as follows:-8,-4and 2 for $\sigma^{2}$ significant at $0.01,0.05$ and 0.1 probability levels, respectively and zero for insignificant $\sigma^{2}$ (the higher value of indicated that $\sigma^{2}$ less stable genotype); (vii) summing adjusted yield rank and stability rating for each genotype to determine $\mathrm{Ys}_{i}$ sistatistic (viii) calculating mean, viii) calculating mean $\mathrm{Ys}_{i}$ and indentifies genotype with $\mathrm{Ys}_{i}$ greater than mean $\mathrm{Ys}_{i}$ to be characterized by stability of high performance i.e stable and high yielding.

\section{RESULTS AND DISCUSSION}

\subsection{Genotype $x$ environment interactions}

Pooled analyses of variance for all six traits across the twelve environments are presented in Table (2). The analysis of variance for stability revealed highly significant differences between the genotypes (Table 2), which suggested that the genotypes differed considerably with respect to yield performance.

Joint regression analysis $\mathrm{s}$ of variance 
revealed that the mean squares due to genotypes (G) and environment (E) difference tested against the $G \times E$ interaction were significant for all the traits studied, indicating the presence of wide variability among the genotypes as well as environments under which the experiments were conducted. The significant estimates of $\mathrm{G} \times \mathrm{E}$ interaction indicated that the characters were unstable and may considerably fluctuate with change in the experiments. These finding are in close agreement with Kumaresani and Nadarajan (2005).

Environment + (genotype $\mathrm{x}$ environment) interaction was partitioned into environment (linear), genotype $\mathrm{x}$ environment (linear) interaction (sum of squares due to regression, $b_{i}$ ) and unexplained deviation from regression (pooled deviation mean squares, $\mathrm{S}^{2} \mathrm{~d}$ ). Insignificant genotype $\mathrm{x}$ environment linear mean squares for studied four traits indicated that the genotypes did not differ genetically in their response to different environments when tested with pooled deviation. On the other hand, the highly significant pooled deviation for the studied traits indicated that most of the studied sesame genotypes significantly differed regarding the deviation from their respective average linear response.

With respect to the analysis of variance for stability variance methods, results in Table (3) indicated that GE interaction was significant for the studied traits. Partitioning the GE interaction revealed that heterogeneity caused by the environmental index was significant for all traits.

The significant residual of all traits indicated that the non-linear components were also significant. These findings are in agreement with those obtained by El-Nakhlawy and Mohamed (2009) and Sedeck et al. (2014a and b). Therefore; it could be concluded that it is essential to determine the stability degree for each genotype. Results of the four stability methods will be discussed for each trait separately.

\subsection{Plant height}

Results of stability parameters for plant height of sesame calculated using different stability methods for the 15 sesame genotypes are presented in Table (4). The results clearly indicated that plant height was significantly affected by genotypes. The highest plant height of sesame was given by genotype No. 12 $(231.166 \mathrm{~cm})$ followed by genotypes No. 11, 2, $13,9,4$ and $5(219.69,218.14,210.50,207.00$,
203.94 and $200.11 \mathrm{~cm}$, respectively). On the other hand, the lowest plant height of sesame was given by genotypes No.1, 6 and 7 recording $174.97,176.36$ and $177.78 \mathrm{~cm}$, respectively.

The results of phenotypic stability indicated that the value of regression coefficient did not significantly differ from unity $(b=1)$ for the studied genotypes, except for genotypes No.1, 9and 13. Also, values of deviation from regression $\left(S^{2} d_{i}\right)$ were not significantly different from zero $\left(S^{2} \mathrm{~d}=0\right)$ for all genotypes except for genotypes No. 2, 3, 7, 8, 9, 11, 13 and 14. Actually $b$ measures the reaction of the genotypes to the environmental effects, then it is considered as a parameter of response, while, the value of deviation from regression $\left(\mathrm{S}^{2} \mathrm{~d}_{\mathrm{i}}\right)$ exhibits the degree of stability. Mean performance of plant height of sesame for genotypes No. 2, 4, 5, $9,11,12$ and 13 were greater than that of all genotypes. It is evident that genotypes No. 4, 5 and 12 had regression coefficient and deviation from regression did not significantly differ from one and zero, respectively. Moreover, it had mean performance significantly greater than the mean of all genotypes. Therefore, genotypes No. 4,5 , and 12 met stability characteristics of the stable genotypes as described by Eberhart and Russell (1966) and could be recommended as a stable genotype for plant height of sesame.

With regard to genotypic stability, the results in Table (4) and Fig. (1) showed that six genotypes No. 2, 3, 7, 11, 12 and 15 (Fig.1) exhibited an average degree of stability. The distribution of $\lambda$ statistic indicates that it was greater than unity for 10genotypes which were unstable for plant height. Concerning stability variance Shukla (1972), examining value of $\sigma^{2}{ }_{i}$ for plant height, displayed in Table (4), cleared that all genotypes were unstable and they had

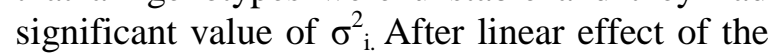
environmental index (a covariate) was removed and $S^{2}$ values were examined, the all studied fifteen genotypes continued to be considered unstable.

Necessary statistics for evaluating sesame genotypes using $\mathrm{Ys}_{i}$ stability for plant height according to Kang and Magari (1995) are presented in Table (4). The results clearly indicated that 7 genotypes out of 15 showed stability of high performance for plant height. They had $\mathrm{Ys}_{i}$ value greater than the mean $\mathrm{Ys}_{i}$. Genotypes No. 1, 3, 6, 7, 8, 10, 14 and 15 had values of $\mathrm{Ys}_{i}$ less than the mean $\mathrm{Ys}_{i}$, so they were considered unstable for plant height of sesame. 
Table (2): Joint regression analysis of variance for all traits studied of the fifteen genotypes tested in twelve environments.

\begin{tabular}{|c|c|c|c|c|c|c|c|}
\hline $\begin{array}{l}\text { Source of } \\
\text { variation }\end{array}$ & d.f & $\begin{array}{c}\text { Plant } \\
\text { height }\end{array}$ & $\begin{array}{l}\text { Fruiting } \\
\text { zone Length }\end{array}$ & $\begin{array}{c}\text { Number of } \\
\text { capsules/ plant }\end{array}$ & $\begin{array}{c}\text { Seed } 1000 \\
\text { weight }\end{array}$ & $\begin{array}{c}\text { Seed weight } \\
\text { plant }\end{array}$ & $\begin{array}{c}\text { Seed yield } \\
(\text { ard/fed })\end{array}$ \\
\hline Genotypes & 14 & $3636.04 * *$ & $1625.25^{* *}$ & $12862.66^{* *}$ & $1.28 * *$ & $237.17 * *$ & $4.01 * *$ \\
\hline Environments & 11 & $32487.41 * *$ & $28351.36^{* * *}$ & $82762.37 * *$ & $4.83 * *$ & $2483.37 * *$ & $41.43^{* * *}$ \\
\hline $\mathrm{G} \times \mathrm{E}$ & 154 & $1806.17 * *$ & $816.95 * *$ & $1860.54 * *$ & $0.20 * *$ & $39.40 * *$ & $1.65 * *$ \\
\hline Total & 179 & & & & & & \\
\hline Env+(G*Env $)$ & 165 & $1283.86^{* *}$ & $884.19 * *$ & $2417.99 * *$ & $0.17 * *$ & $67.44 * *$ & $1.43 * *$ \\
\hline Environment(linear) & 1 & $.119119 * *$ & $103957.00^{* * *}$ & $303462.30^{* * *}$ & $17.69^{* * *}$ & $9105.72^{* *}$ & $151.92 * *$ \\
\hline $\mathrm{G}^{*}$ Env(linear) & 14 & $256.79^{*}$ & $695.99 * *$ & $1101.58^{*}$ & $0.17 * *$ & $20.87 *$ & $0.84 *$ \\
\hline Poold deviation & 150 & $1980.51 * *$ & $214.61 * *$ & $533.89 * *$ & $0.05 * *$ & $11.54 * *$ & $0.49 * *$ \\
\hline 1 & 10 & 206.42 & 38.07 & $568.36^{* *}$ & $0.06 * *$ & $16.67 * *$ & $0.52 * *$ \\
\hline 2 & 10 & $521.90 * *$ & $217.45 * *$ & $2105.77 * *$ & $0.35 * *$ & $38.18^{* * *}$ & $1.24 * *$ \\
\hline 3 & 10 & $607.53 * *$ & $231.29 * *$ & 124.48 & 0.02 & 4.39 & $0.18 * *$ \\
\hline 4 & 10 & 69.20 & 50.59 & 95.42 & 0.01 & 3.71 & 0.15 \\
\hline 5 & 10 & 113.27 & $252.75 * *$ & $303.31 * *$ & 0.01 & 5.24 & 0.13 \\
\hline 6 & 10 & 72.21 & 66.29 & 87.18 & 0.002 & $8.37 * *$ & $0.35 * *$ \\
\hline 7 & 10 & $570.46^{* * *}$ & 150.08 & $2318.17^{* *}$ & 0.01 & $17.27 * *$ & $0.52 * *$ \\
\hline 8 & 10 & $794.16^{* * *}$ & 197.88 & $245.19^{* *}$ & 0.02 & $26.17^{* * *}$ & $1.03 * *$ \\
\hline 9 & 10 & $1667.05^{* *}$ & $375.43 * *$ & $272.50 * *$ & 0.02 & $8.34 * *$ & $0.40 * *$ \\
\hline 10 & 10 & 38.71 & 186.28 & $1166.80^{* *}$ & $0.06^{* *}$ & 2.01 & 0.08 \\
\hline 11 & 10 & $735.92 * *$ & 43.80 & $169.30^{* *}$ & 0.01 & $9.53 * *$ & $0.38^{* *}$ \\
\hline 12 & 10 & 183.79 & 118.69 & 75.82 & 0.03 & 6.42 & $1.22 * *$ \\
\hline 13 & 10 & $2351.85^{* *}$ & $877.86^{* *}$ & 41.83 & 0.02 & $7.13 * *$ & $0.26^{* *}$ \\
\hline 14 & 10 & $800.32 * *$ & 144.41 & 80.40 & 0.05 & $10.47 * *$ & $0.35^{* *}$ \\
\hline 15 & 10 & 179.30 & $268.34 * *$ & $353.88^{* * *}$ & $0.10 * *$ & $9.16^{* * *}$ & $0.50^{* * *}$ \\
\hline Pooled error & 360 & 114.94 & 83.51 & 60.24 & 0.02 & 2.92 & 0.07 \\
\hline
\end{tabular}

Table (3): Analysis of variance for Shukla's stability variance and Kang's methods.

\begin{tabular}{|l|c|c|c|c|c|c|c|}
\hline $\begin{array}{c}\text { Source of } \\
\text { variation }\end{array}$ & d.f & Plant height & $\begin{array}{c}\text { Fruiting zone } \\
\text { Length }\end{array}$ & $\begin{array}{c}\text { Number of } \\
\text { capsules/ plant }\end{array}$ & $\begin{array}{c}\text { 1000-seed } \\
\text { weight }\end{array}$ & $\begin{array}{c}\text { Seed weight } \\
\text { plant }\end{array}$ & $\begin{array}{c}\text { Seed yield } \\
\text { (ard/fed) }\end{array}$ \\
\hline Total & 179 & & & & & & \\
\hline Genotypes & 14 & $10908.32^{* *}$ & $4875.27^{* *}$ & $38588.09^{* *}$ & $3.84^{* *}$ & $711.51^{* *}$ & $12.04^{* *}$ \\
\hline Environments & 11 & $32487.41^{* *}$ & $28351.36^{* *}$ & $82762.37^{* *}$ & $4.83^{* *}$ & $2483.37^{* *}$ & $41.43^{* *}$ \\
\hline G*Env & 154 & $1806.17^{* *}$ & $816.95^{* *}$ & $1860.54^{* *}$ & $0.20^{* *}$ & $39.40^{* *}$ & $1.65^{* *}$ \\
\hline Heterogeneity & 14 & $770.68^{* *}$ & $2088.16^{* *}$ & $3304.90^{* *}$ & $0.52^{* *}$ & $62.61^{* *}$ & $2.52^{* *}$ \\
\hline Residual & 140 & $1909.72^{* *}$ & $689.83^{* *}$ & $1716.11^{* *}$ & $0.17^{* *}$ & $37.08^{* *}$ & $1.57^{* *}$ \\
\hline Poold error & 336 & 114.94 & 83.51 & 60.24 & 0.02 & 0.03 & 0.07 \\
\hline
\end{tabular}

Table (4): Mean performance of plant height and phenotypic, genotypic, Shukla's and Kang and Magari stability measurements for fifteen sesame genotypes over 12 environments.

\begin{tabular}{|c|c|c|c|c|c|c|c|c|}
\hline \multirow{2}{*}{ Genotypes } & \multirow{2}{*}{ Mean } & \multicolumn{2}{|c|}{ Phenotypic stability } & \multicolumn{2}{|c|}{ Genotypic stability } & \multicolumn{2}{|c|}{ Shukla's Stability } & \multirow{2}{*}{$\begin{array}{c}\begin{array}{c}\text { Kang\& Magari } \\
\text { stability }\end{array} \\
Y_{s_{i}} \\
\end{array}$} \\
\hline & & $\mathbf{b}_{\mathbf{i}}$ & $\mathrm{S}^{2} \mathrm{di}$ & $\boldsymbol{\alpha}_{\mathrm{i}}$ & $\lambda_{\mathrm{i}}$ & Sigma square & S-square & \\
\hline 1 & 174.97 & $0.72 *$ & 201.03 & $-0 . .32$ & 35.34 & $700.07 * *$ & $567.61 * *$ & -10 \\
\hline 2 & 218.14 & 1.08 & $516.6 * *$ & 0.09 & 94.18 & $1517.66^{* * *}$ & $1659.64 * *$ & +8 \\
\hline 3 & 191.53 & 0.95 & $602.14 * *$ & -0.06 & 109.75 & $1778.84 * *$ & $1956.13 * *$ & -4 \\
\hline 4 & 203.94 & 1.09 & 63.82 & 0.11 & 12.30 & $98.67 * *$ & $92.62 * *$ & +4 \\
\hline 5 & 200.11 & 1.20 & 107.88 & 0.24 & 19.41 & $320.47 * *$ & $245.17 * *$ & +2 \\
\hline 6 & 176.36 & 0.92 & 66.82 & -0.09 & 12.89 & $104.35 * *$ & $103.06^{* *}$ & -9 \\
\hline 7 & 177.78 & 1.05 & $565.07 * *$ & 0.06 & 103.03 & $1663.57 * *$ & $1827.79 * *$ & -8 \\
\hline 8 & 181.50 & 1.25 & $788.77 * *$ & 0.29 & 141.99 & $2510.27 * *$ & $2602.06^{* *}$ & -7 \\
\hline 9 & 207.00 & $1.34 *$ & $1661.66^{* * *}$ & 0.41 & 298.25 & $5403.81 * *$ & $5623.61 * *$ & +6 \\
\hline 10 & 182.17 & 0.91 & 33.33 & -0.11 & 6.76 & $5.32 * *$ & -12.94 & -6 \\
\hline 11 & 219.69 & 0.97 & $730.54 * *$ & -0.03 & 132.99 & $2178.81 * *$ & $2400.52 * *$ & +9 \\
\hline 12 & 231.17 & 1.02 & 178.40 & 0.03 & 33.21 & $440.89 * *$ & $489.32 * *$ & +10 \\
\hline 13 & 210.50 & $0.71 *$ & $2346.46^{* * *}$ & -0.34 & 422.99 & $7465.24 * *$ & $7994.11 * *$ & +7 \\
\hline 14 & 196.64 & 0.80 & $794.94 * *$ & -0.23 & 143.65 & $2477.23 * *$ & $2623.44 * *$ & -1 \\
\hline 15 & 194.00 & 0.97 & 173.91 & -0.03 & 32.39 & $427.02 * *$ & $473.74 * *$ & -2 \\
\hline Grand mean & 197.7 & 1.0 & & & & & & -0.06 \\
\hline
\end{tabular}

Bold cells indicate to the stable genotypes 


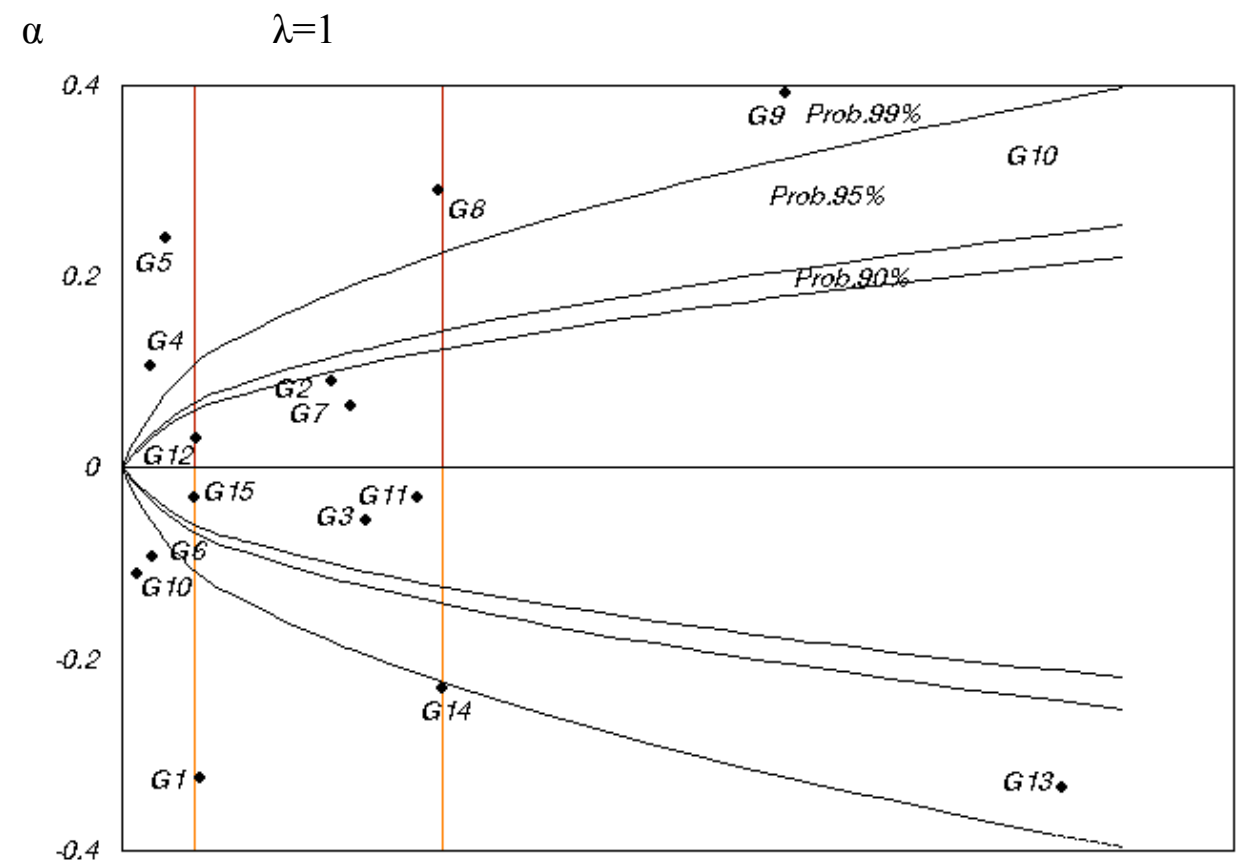

$\lambda$

Fig. (1): Distribution of stability statistics for plant height

\subsection{Fruiting zone Length}

Results of stability parameters for fruiting zone length of sesame calculated using different stability methods for the 15 sesame genotypes are presented in Table (5). The results clearly indicated that the highest fruiting zone Length was given by genotype No. $12(154.36 \mathrm{~cm})$ followed by genotypes No.13, 5, 9, 4, 11, 2 and 15 that recorded 148.94, 148.88, 141.44, 140.75, $138.50,136.16$ and $135.16 \mathrm{~cm}$, respectively. On the other hand, the least fruiting zone length of sesame was given by genotypes No. 8, 6, 10, 1, 7,3 and 14 recording $114.28,117.78,124.47$, $125.50,126.22, \quad 128.58$ and $131.83 \mathrm{~cm}$, respectively.

The results of phenotypic stability indicated that the value of regression coefficient did not significantly differ from unity $(b=1)$ for all the studied genotypes except for genotypes No. 2, 3, $5,6,8,12,13,14$ and 15 . Also, values of deviation from regression $\left(S^{2} d\right)$ were not significantly different from zero $\left(\mathrm{S}^{2} \mathrm{~d}=0\right)$ for the genotypes except for genotypes No. 2, 3, 5, 9, 13 and 15. Actually, $b$ measures the reaction of the genotypes to the environmental effects, then it is considered as a parameter of response, while, the value of deviation from regression $\left(S^{2} d\right)$ exhibits the degree of stability. It is evident that genotypes No. 4 and 11 had regression coefficient and deviation from regression did not significantly differ from one and zero, respectively. Moreover, it had a mean performance greater than the mean of all genotypes. Therefore, genotypes No. 4 and 11 met stability characteristics of the stable genotypes as described by Eberhart and Russell (1966) and could be recommended as a stable genotypes for fruiting zone Length of sesame. These results agree with Kumaresani and Nadarajan (2005) and Sedeck et al. (2014 b).

Results in Table (5) and Fig. (2) cleared that an average degree of genotypic stability was shown, for fruiting zone length, by four genotypes (4, 7, 9 and 10) out of 15. The distribution of $\lambda$ statistic indicates that it was greater than unity for the rest of genotypes (Fig 2), indicating the importance of the unpredictable component of GE interaction and these genotypes were unstable for fruiting zone length.

Concerning stability-variance of Shukla's (1972), examining value of $\sigma_{i}^{2}$ for fruiting zone length of sesame, displayed in Table (5), cleared that all genotypes were unstable and they had a significant value of $\sigma_{i}^{2}$. After linear effect of the environmental index (a covariate) was removed and $S^{2}$ values were examined, all studied fifteen genotypes continued to be considered unstable.

The statistics required for evaluating sesame genotypes using $\mathrm{Ys}_{i}$ stability for fruiting zone length according to Kang and Magari (1995) are presented in Table (5). The results clearly 
Table (5): Mean performance of fruiting zone Length and phenotypic, genotypic, Shukla's and Kang and Magari stability measurements for fifteen sesame genotypes over 12 environments.

\begin{tabular}{|c|c|c|c|c|c|c|c|c|}
\hline \multirow{2}{*}{ Genotypes } & \multirow{2}{*}{ Mean } & \multicolumn{2}{|c|}{ Phenotypic stability } & \multicolumn{2}{|c|}{ Genotypic stability } & \multicolumn{2}{|c|}{ Shukla's stability } & \multirow{2}{*}{$\begin{array}{c}\text { Kang\&Magari stability } \\
Y_{s_{\mathbf{i}}} \\
\end{array}$} \\
\hline & & $\mathbf{b}_{\mathbf{i}}$ & $\mathbf{S}^{2} \mathbf{d}_{\mathbf{i}}$ & $\alpha_{i}$ & $\lambda$ & Sigma square & S- square & \\
\hline 1 & 125.50 & 0.98 & 33.63 & -0.028 & 8.32 & $58.26^{* *}$ & $78.73 * *$ & -7 \\
\hline 2 & 136.17 & $0.73 *$ & $213.00 * *$ & -0.31 & 46.01 & $781.58 * *$ & $699.61 * *$ & +2 \\
\hline 3 & 128.58 & $1.21 *$ & $226.85 * *$ & 0.24 & 49.72 & $756.95 * *$ & $747.58 * *$ & -4 \\
\hline 4 & 140.75 & 1.13 & 46.147 & 0.143 & 10.74 & $130.39 * *$ & $122.06^{* *}$ & +5 \\
\hline 5 & 148.89 & $1.34 *$ & $248.30^{* *}$ & 0.389 & 52.82 & $984.04 * *$ & $821.82 * *$ & +8 \\
\hline 6 & 117.78 & $1.23 *$ & 61.88 & 0.26 & 13.41 & $256.39 * *$ & $176.39 * *$ & -9 \\
\hline 7 & 126.22 & 1.16 & 145.63 & 0.18 & 32.29 & $465.43^{* *}$ & $466.43 * *$ & -6 \\
\hline 8 & 114.28 & $1.29 *$ & 193.44 & 0.34 & 41.42 & $750.73 * *$ & $631.91 * *$ & -10 \\
\hline 9 & 141.44 & 1.15 & $370.99 *$ & 0.17 & 81.74 & $1165.02 * *$ & $1246.49 * *$ & +7 \\
\hline 10 & 124.47 & 1.08 & 181.84 & 0.09 & 40.64 & $538.03 * *$ & $591.76 * *$ & -8 \\
\hline 11 & 138.50 & 1.02 & 39.35 & 0.02 & 9.59 & $75.49 * *$ & $98.55 * *$ & -4 \\
\hline 12 & 154.36 & $1.26^{*}$ & 114.25 & 0.30 & 24.46 & $462.99 * *$ & $357.80 * *$ & +10 \\
\hline 13 & 148.94 & $0.26^{*}$ & $873.42 * *$ & -0.85 & 180.06 & $3911.76^{* * *}$ & $2985.70 * *$ & +9 \\
\hline 14 & 131.83 & $0.65 *$ & 139.97 & -0.40 & 28.93 & $660.26^{* *}$ & $446.80 * *$ & -2 \\
\hline 15 & 135.17 & $0.53 *$ & $263.89 * *$ & -0.53 & 53.99 & $1556.63 * *$ & $875.80 * *$ & +1 \\
\hline Grand mean & 134.19 & 1.0 & & & & & & $\mathbf{0}$ \\
\hline
\end{tabular}

Bold cells indicate to the stable genotypes

a $\lambda=1$

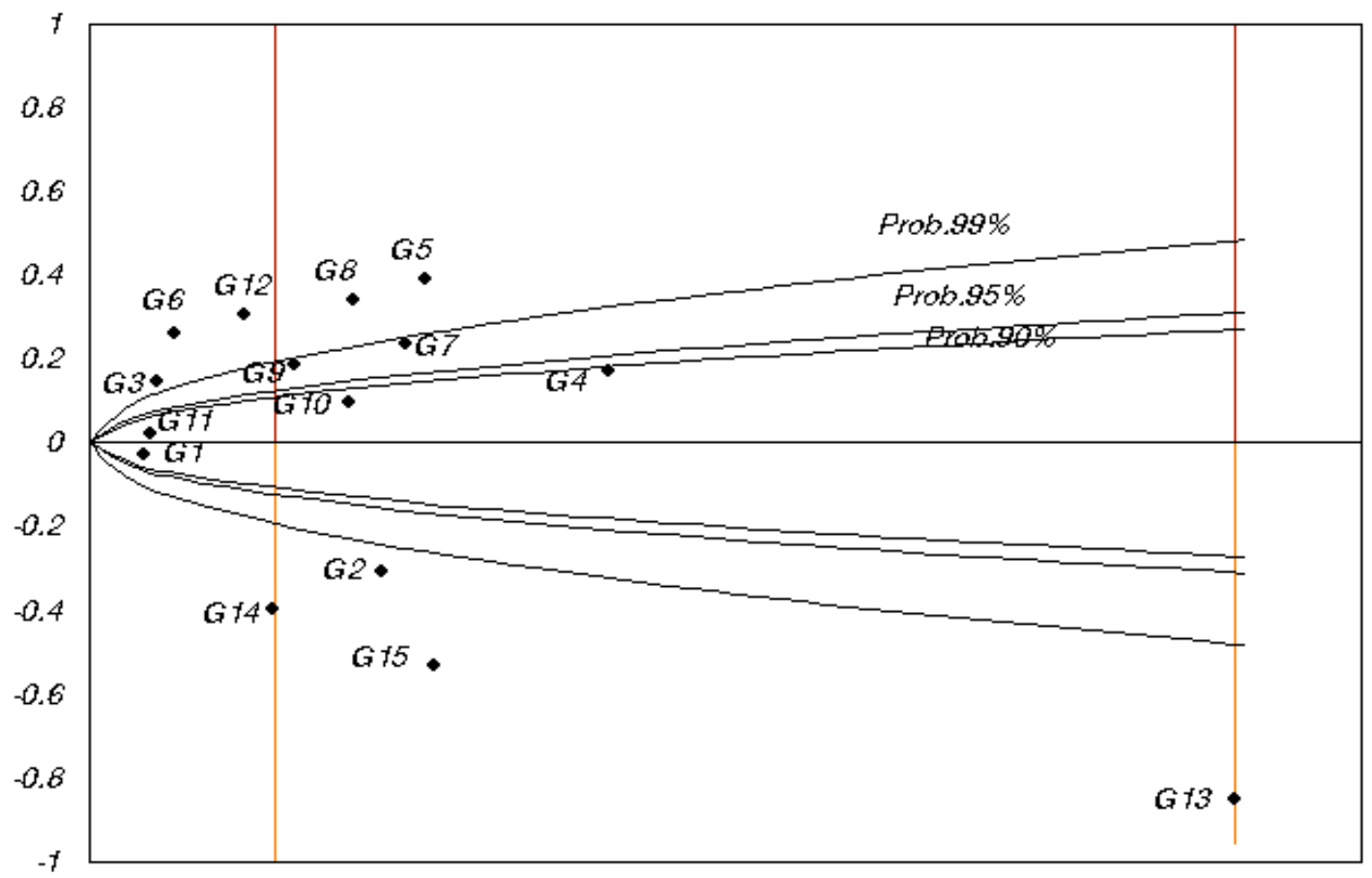

$\lambda$

Fig. (2): Distribution of stability statistics for fruiting zone length.

indicated that 8 out of 15 genotypes showed stability of high performance for fruiting zone length. They had $\mathrm{Ys}_{i}$ value greater than the mean $\mathrm{Ys}_{i}$. Genotypes No. 1, 3, 6, 7, 8, 10, 14 and 15 had values of $\mathrm{Ys}_{i}$ less than the mean $\mathrm{Ys}_{i}$, so they were declared unstable for fruiting zone length of sesame.

\subsection{Number of capsules/plant}

Results of mean performance and stability measurements for the number of capsules/plant are shown in Table (6). Results indicated that the number of capsules / plant ranged from 186.416 for genotype No. 8 to 73.39 for genotype No. 11 . On the other hand, the lowest numbers of capsules / plant of sesame were given by genotypes No. 2, 3, 4, 5, 9, 11 and 15 recording 131.22, 114.92, 103.44, 122.94, 86.31, 73.39 and 111.89 , respectively.

Phenotypic stability cleared that the value of regression coefficient did not significantly differ 
from unity $(b=1)$ for all the studied genotypes, except for genotypes No. 1, 2, 7 and 10. Also, values of deviation from regression $\left(\mathrm{S}^{2} \mathrm{~d}\right)$ were not significantly different from zero $\left(S^{2} d_{i}=0\right)$ for all genotypes, except for genotypes No. 1, 2, $5,7,8,9,10,11$ and 15 . Actually b measures the reaction of the genotypes to the environmental effects, then it is considered as a parameter of response, while, the value of deviation from regression $\left(\mathrm{S}^{2} \mathrm{~d}\right)$ exhibits the degree of stability. Mean performance of the numbers of capsules/plant of sesame for genotypes No. 8, 1, $6,13,12,10,4$ and 7 were greater than that of all genotypes. It is evident that genotypes No. 6, 12,13 and 14 had regression coefficient and deviation from regression did not significantly differ from one and zero, respectively. Moreover, it had a mean performance significantly greater than the mean of all genotypes. Therefore, genotypes No. 6, 12, 13 and 14 met stability characteristics of the stable genotypes as described by Eberhart and Russell (1966).

With regard to genotypic stability, the results in Table (6) and Fig. (3) showed that 5 genotypes, namely No 5, 6, 8, 9 and 11 , exhibited an average degree of stability. The distribution of $\lambda$ statistic indicates that it was greater than unity for 10 genotypes out of 15 indicating the importance of the unpredictable component of GE interaction and these genotypes were unstable for the number of capsules / plant.

Concerning stability-variance Shukla's (1972), examining value of $\sigma_{i}^{2}$ for the number of capsules/plant of sesame, displayed in Table 6, cleared that all genotypes were unstable and they had significant values of $\sigma_{\mathrm{i}}^{2}$. After linear effect of the environmental index (a covariate) was removed and $S^{2}$ values were examined, the above mentioned fifteen genotypes continued to be considered unstable. The statistics needed for evaluating sesame genotypes using $\mathrm{Ys}_{i}$ stability for number of capsules/plant according to Kang and Magari (1995) are presented in Table 6. The results clearly indicated that 8 genotypes out of 15 showed stability of high performance for number of capsules/plant. They had $\mathrm{Ys}_{i}$ value greater than the mean $\mathrm{Ys}_{i}$. Genotypes No. 2, 3, 4, $5,9,11$ and 15 had values of $\mathrm{Ys}_{i}$ less than the mean $\mathrm{Ys}_{i}$, so they were declared unstable for number of capsules/plant of sesame.

\subsection{0 seed weight}

Table (7) represents the results of stability measurements for 1000 seed weight using different stability methods to evaluate fifteen sesame genotypes. The results clearly showed that 1000 seed weight was significantly affected by sesame genotypes. However, six genotypes namely No. 12, 2, 5, 14, 10 and lgave the highest values for 1000 seed weight. These values were $3.49 \mathrm{~g}, 3.35 \mathrm{~g}, 3.09 \mathrm{~g}, 3.01 \mathrm{~g}, 2.99$

Table (6): Mean number of capsules/plant and phenotypic, genotypic, Shukla's and Kang and Magari stability measurements for fifteen sesame genotypes across12 environments.

\begin{tabular}{|c|c|c|c|c|c|c|c|c|}
\hline \multirow{2}{*}{ Genotypes } & \multirow{2}{*}{ Mean } & \multicolumn{2}{|c|}{ Phenotypic stability } & \multicolumn{2}{|c|}{ Genotypic stability } & \multicolumn{2}{|c|}{ Shukla's stability } & \multirow{2}{*}{$\frac{\text { Kang\&Magari stability }}{\mathrm{Ys}_{i}}$} \\
\hline & & $\mathbf{b}_{\mathbf{i}}$ & $\mathbf{S}^{2} \mathbf{d}_{\mathrm{i}}$ & $\boldsymbol{\alpha}_{\mathrm{i}}$ & $\lambda_{\mathrm{i}}$ & Sigma & S- square & \\
\hline 1 & 182.86 & $0.68^{*}$ & $560.44 * *$ & -0.33 & 69.04 & $2286.32 * *$ & $1835.40 * *$ & +9 \\
\hline 2 & 131.42 & $1.52 *$ & $2097.85 * *$ & 0.53 & 256.56 & $8191.55^{* *}$ & $7157.28 * *$ & -2 \\
\hline 3 & 114.92 & 0.89 & 116.56 & -0.11 & 15.20 & $320.98 * *$ & $298.90 * *$ & -6 \\
\hline 4 & 103.44 & 1.13 & 87.50 & 0.13 & 11.60 & $259.17 * *$ & $198.31 * *$ & -8 \\
\hline 5 & 122.94 & 0.97 & $295.39 * *$ & -0.03 & 37.23 & $817.18^{* *}$ & $917.93 * *$ & -5 \\
\hline 6 & 167.28 & 1.04 & 79.26 & 0.04 & 10.69 & $141.83 * *$ & $169.76^{* *}$ & +8 \\
\hline 7 & 134.72 & $1.39 *$ & $2310.25^{* *}$ & 0.41 & 238.45 & $8160.77 * *$ & $7892.49 * *$ & +1 \\
\hline 8 & 186.42 & 1.03 & $237.27 * *$ & 0.03 & 30.09 & $635.59 * *$ & $716.74 * *$ & +10 \\
\hline 9 & 86.31 & 0.98 & $264.58 * *$ & -0.03 & 33.45 & $718.32 * *$ & $811.27 * *$ & -9 \\
\hline 10 & 138.06 & $0.61 *$ & $1158.88^{* *}$ & -0.40 & 142.13 & $4497.88^{* *}$ & $3906.96^{* * *}$ & +4 \\
\hline 11 & 73.39 & 0.88 & $161.38^{* *}$ & -0.12 & 20.69 & $475.72 * *$ & $454.03 * *$ & -10 \\
\hline 12 & 152.81 & 0.93 & 67.90 & -0.07 & 9.28 & $122.67 * *$ & $130.44 * *$ & +6 \\
\hline 13 & 156.92 & 0.91 & 33.91 & -0.09 & 5.08 & $35.85 * *$ & $12.80^{* *}$ & +7 \\
\hline 14 & 137.19 & 1.12 & 72.48 & 0.13 & 9.76 & $206.14 * *$ & $146.33^{* *}$ & +3 \\
\hline 15 & 111.89 & 0.90 & $345.96^{* *}$ & -0.11 & 43.37 & $1037.95^{* *}$ & $1092.97 * *$ & -7 \\
\hline Grand mean & 133.37 & 1.0 & & & & & & 0.06 \\
\hline
\end{tabular}

Bold cells indicate to the stable genotypes. 
a

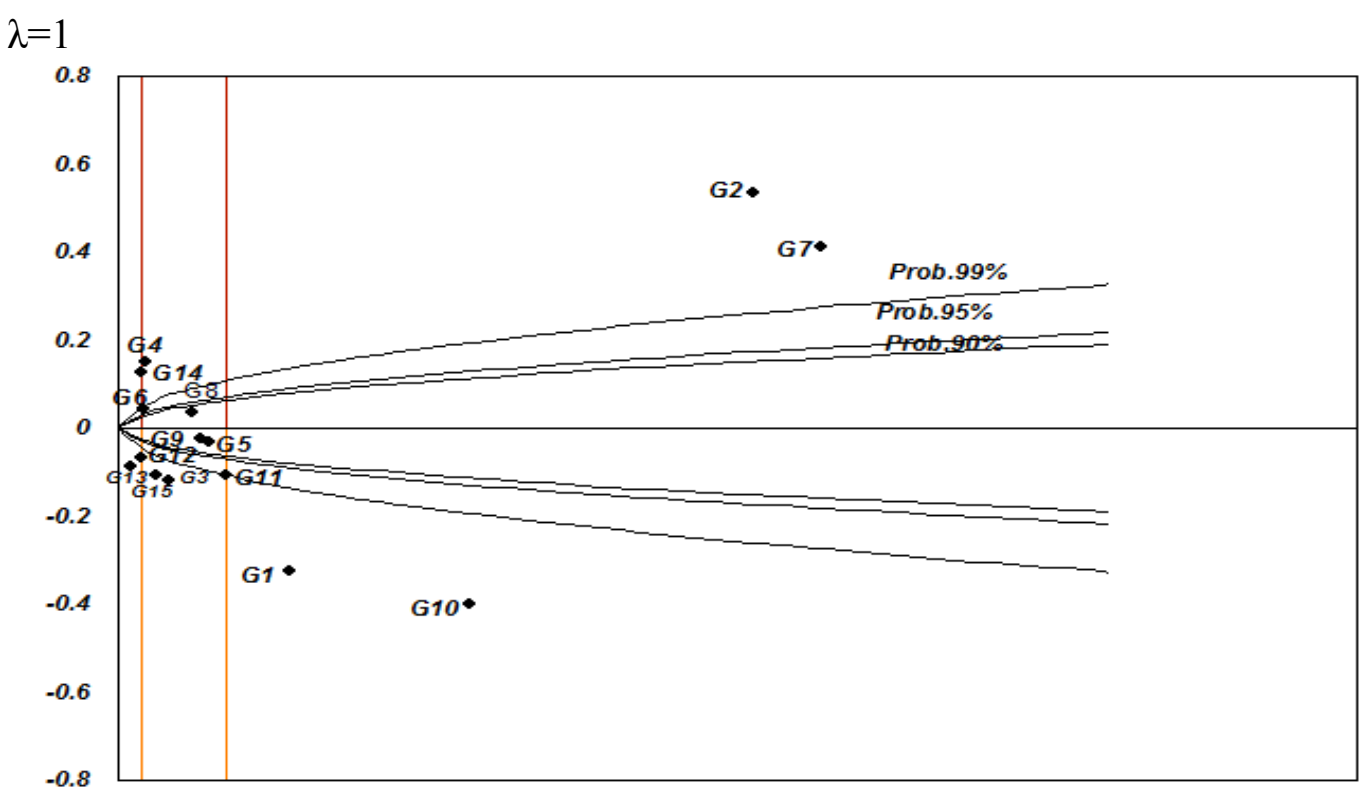

$\lambda$

Fig. (3): Distribution of stability statistics for number of capsules/plant

$\mathrm{g}$, and $2.83 \mathrm{~g}$ for corresponding genotypes, respectively. Genotypes No. 8 and 9 being 2.48 and $2.41 \mathrm{~g}$, respectively gave the lowest 1000 seed weight. Results of the phenotypic stability showed that the regression coefficients were not significantly differing from unity for 8 genotypes. Deviation from regression $\left(\mathrm{S}^{2} \mathrm{~d}\right)$ values did not significantly differ from zero except for genotypes No. 1, 2, 10 and 15. The results cleared that out of 15 genotypes there no one was phenotypically stable according to the rules described by Eberhart and Russell (1966). Results in Table (7) and Fig. (4) cleared that out of the 15 genotypes, only 5 showed genotypic stability of an average degree indicating less response to the environmental change and therefore, they were more adaptive for specific environment. The distribution indicated that $\lambda$ statistic was greater than unity for the other genotypes suggesting the importance of the unpredictable component of genotype $x$ environment interaction, (Fig. 4) and these genotypes were declared unstable.

Results of stability variance method of Shukla's (1972) indicated that all the genotypes were unstable except genotype No. 6 of both $\sigma^{2}$; and $\mathrm{S}^{2}$. Seven genotypes out of 15 were characterized by stability of high performance for 1000 seed weight according to Kang and Maganri (1995) method as shown in Table (7).

Table (7): Mean of 1000 seed weight and phenotypic, genotypic, Shukla's and Kang and Magari stability measurements for fifteen sesame genotypes across 12 environments.

\begin{tabular}{|c|c|c|c|c|c|c|c|c|}
\hline \multirow[t]{2}{*}{ Genotypes } & \multirow[t]{2}{*}{ Mean } & \multicolumn{2}{|c|}{ Phenotypic stability } & \multicolumn{2}{|c|}{ Genotypic stability } & \multicolumn{2}{|c|}{ Shukla's stability } & \multirow{2}{*}{$\begin{array}{c}\begin{array}{c}\text { Kang\&Magari } \\
\text { stability }\end{array} \\
Y_{s_{i}}\end{array}$} \\
\hline & & $\mathbf{B i}$ & $S^{2} d$ & $\alpha$ & $\lambda$ & Sigma square & S- square & \\
\hline 1 & 2.82 & $1.26^{*}$ & $0.06^{* *}$ & 0.31 & 8.76 & $0.21 * *$ & $0.21 * *$ & $3+$ \\
\hline 2 & 3.35 & 0.13 & $0.34 * *$ & -1.05 & 46.47 & $1.37 * *$ & $1.20 * *$ & 9+ \\
\hline 3 & 2.59 & 1.14 & 0.01 & 0.16 & 2.34 & $0.05^{* *}$ & $0.05 * *$ & -5 \\
\hline 4 & 2.69 & 1.10 & 0.01 & 0.12 & 1.76 & $0.03 * *$ & $0.03^{* *}$ & -2 \\
\hline 5 & 3.09 & $0.77 *$ & 0.01 & -0.28 & 1.87 & $0.05 * *$ & $0.04 * *$ & $8+$ \\
\hline 6 & 2.59 & 0.91 & -0.004 & -0.11 & 0.36 & -0.003 & -0.035 & $2+$ \\
\hline 7 & 2.50 & $0.74 *$ & 0.001 & -0.31 & 1.44 & $0.05 * *$ & $0.28 * *$ & -8 \\
\hline 8 & 2.48 & 1.03 & 0.01 & 0.04 & 2.80 & $0.05 * *$ & $0.06^{* *}$ & -9 \\
\hline 9 & 2.41 & $0.70 *$ & 0.01 & -0.36 & 2.61 & $0.08 * *$ & $0.06 * *$ & -10 \\
\hline 10 & 2.99 & 0.88 & $0.06^{* *}$ & -0.15 & 9.01 & 0.19 ** & $0.21 * *$ & $6+$ \\
\hline 11 & 2.50 & 0.93 & 0.01 & -0.08 & 2.05 & $0.03^{* *}$ & $0.04 * *$ & -7 \\
\hline 12 & 3.49 & $1.43 *$ & 0.03 & 0.51 & 4.17 & $0.16^{* *}$ & $0.11^{* *}$ & $10+$ \\
\hline 13 & 2.75 & 0.88 & 0.02 & -0.15 & 3.12 & $0.06^{* *}$ & $0.07 * *$ & 0 \\
\hline 14 & 3.01 & $1.29 *$ & 0.05 & 0.35 & 7.02 & $0.18^{* *}$ & $0.17^{* *}$ & $7+$ \\
\hline 15 & 2.65 & $1.82 *$ & $0.10^{* *}$ & 0.99 & 12.04 & $0.56^{* *}$ & $0.34 * *$ & -4 \\
\hline Grand mean & 2.80 & 1.0 & & & & & & $\mathbf{0}$ \\
\hline
\end{tabular}

Bold cells indicate to the stable genotypes 


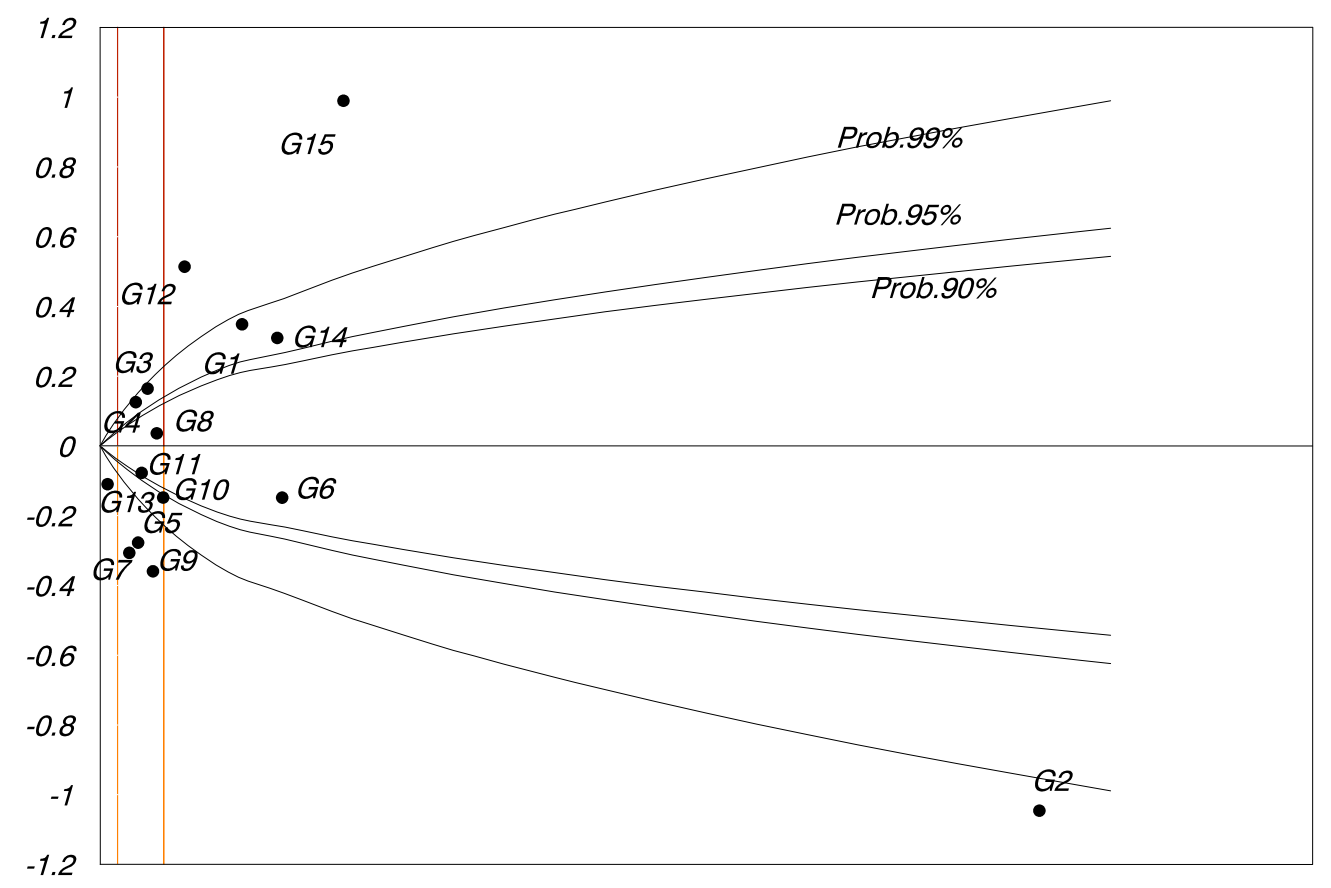

$\lambda$

Fig. (4): Distribution of stability statistics for 1000 seed weight

These genotypes had $\mathrm{Ys}_{i}$ value greater than the mean a $\mathrm{Ys}_{i}$ value. However, the other eight genotypes had a value of $\mathrm{Ys}_{i}$ less than the mean $\mathrm{Ys}_{i}$.Therefore; these genotypes were judged to be unstable. These results are agreement with Gebeyahu and Assefa (2003) and Adebisi et al. (2010).

\subsection{Seed weight/plant}

The results of the four stability methods regarding seed weight/ plant are shown in Table (8). Sesame genotypes significantly affected seed yield. Genotype No. 12 gave the highest value for this trait recording $32.69 \mathrm{~g} / \mathrm{plant}$.

Genotype No. 10 ranked second (24.78 g/plant) followed by genotype No. 5 ( $22.17 \mathrm{~g} / \mathrm{plant})$, No1 (22.18 g/plant) and No. 2 (21.43 g/plant).The lowest seed weight/plant was obtained by genotypes No. 9 (14.50 g/plant) and No. 11 $(14.99 \mathrm{~g} /$ plant $)$. The value of regression coefficient did not significantly differ from unity $(b=1)$ for the studied genotypes, except for 7 ones. Considering the values of deviation from regression $\left(S^{2} \mathrm{~d}\right)$, five genotypes were not significantly different from zero, while genotypes No. 1, 2, 6, 7, 8, 9, 11, 13, 14 and 15 were significantly different. Genotypes No. 12, $10,1,2,3$ and 4 had seed weight /plant greater than the mean of all genotypes. It was observed from the results that genotypes No. 5, 10 and 12 were phenotypically stable for seed weight/plant where they met assumptions of Eberhart and Russell (1966) for stable genotypes. These results are similar to those obtained by Adebisi and Ajala (2006) and Sedeck et al. (2014 b).

The estimates of genotypic stability parameters and means of all genotypes for seed weight/plant are presented in Table (8). Fig. (5) illustrates the $\alpha$ and $\lambda$ distributions of fifteen genotypes. There are only two genotypes (G14and G15) for seed weight/ plant located in the average stable area. The identified genotypes may be used as a source of genetic variability for improvement sesame program in future as discussed for similar genotypes by Kumar et al. (2008), Adebisi (2010) and Suvama et al. (2011) and Sedeck et al. (2014 b).

Concerning stability variance method of Shukla's (1972), results in Table (8) showed that all genotypes were judged to be unstable, where their values of both $\sigma^{2}$ and $S^{2}$ were significant. 
Table (8): Mean seed weight /plant and phenotypic, genotypic, Shukla's and Kang and Magari Stability measurements for fifteen sesame genotypes across 12 environments.

\begin{tabular}{|c|c|c|c|c|c|c|c|c|}
\hline \multirow{2}{*}{ Genotypes } & \multirow{2}{*}{ Mean } & \multicolumn{2}{|c|}{ Phenotypic stability } & \multicolumn{2}{c|}{ Genotypic stability } & \multicolumn{2}{c|}{ Shukla' s stability } & \multicolumn{2}{c|}{ Kang\&Magari stability } \\
\cline { 3 - 8 } & & $\mathbf{b}_{\mathbf{i}}$ & $\mathbf{S}_{\mathbf{d}} \mathbf{d}_{\mathbf{i}}$ & $\mathbf{d}_{\mathbf{i}}$ & $\boldsymbol{\lambda}_{\mathbf{i}}$ & Sigma square & $\mathbf{S}-\mathbf{s q u a r e}$ & \multicolumn{2}{|c|}{$\mathbf{Y s}_{\boldsymbol{i}}$} \\
\hline 1 & 22.18 & $0.82^{*}$ & $15.87^{* *}$ & -0.19 & 20.17 & $55.92^{* *}$ & $54.84^{* *}$ & $\mathbf{+ 8}$ \\
\hline 2 & 21.43 & $1.38^{*}$ & $37.36^{* *}$ & 0.40 & 46.01 & $144.62^{* *}$ & $129.30^{* *}$ & $\mathbf{+ 6}$ \\
\hline 3 & 20.83 & $1.22^{*}$ & 3.59 & 0.23 & 5.19 & $20.02^{* *}$ & $12.34^{* *}$ & $\mathbf{+ 5}$ \\
\hline 4 & 20.44 & $1.21^{*}$ & 2.91 & 0.22 & 4.38 & $17.21^{* *}$ & $9.99^{* *}$ & $\mathbf{+ 4}$ \\
\hline 5 & 22.17 & $\mathbf{1 . 1 0}$ & $\mathbf{4 . 4 4}$ & 0.11 & 6.35 & $15.47^{* *}$ & $15.29^{* *}$ & $\mathbf{+ 7}$ \\
\hline 6 & 20.17 & 0.97 & $7.57^{* *}$ & -0.03 & 10.18 & $23.47^{* *}$ & $26.13^{* *}$ & -2 \\
\hline 7 & 16.83 & $0.86^{*}$ & $16.47^{* *}$ & -0.15 & 20.95 & $55.23^{* *}$ & $56.93^{* *}$ & -7 \\
\hline 8 & 16.61 & $0.68^{*}$ & $25.37^{* *}$ & -0.34 & 31.52 & $99.24^{* *}$ & $87.73^{* *}$ & -8 \\
\hline 9 & 14.50 & 0.94 & $7.56^{* *}$ & -0.07 & 10.13 & $23.98^{* *}$ & $26.01^{* *}$ & -10 \\
\hline 10 & 24.78 & $\mathbf{1 . 1 2}$ & $\mathbf{1 . 2 1}$ & 0.13 & 2.40 & $6.10^{* *}$ & $4.11^{* *}$ & $\mathbf{+ 9}$ \\
\hline 11 & 14.99 & $0.79^{*}$ & $8.73^{* *}$ & -0.22 & 11.46 & $35.46^{* *}$ & $30.12^{* *}$ & -9 \\
\hline 12 & 32.69 & $\mathbf{1 . 0 2}$ & $\mathbf{5 . 6 2}$ & 0.03 & 7.81 & $17.28^{* *}$ & $19.37^{* *}$ & $\mathbf{+ 1 0}$ \\
\hline 13 & 18.06 & 0.90 & $6.33^{* *}$ & -0.10 & 8.64 & $21.23^{* *}$ & $21.82^{* *}$ & -6 \\
\hline 14 & 19.38 & 0.98 & $9.66^{* *}$ & -0.02 & 12.73 & $29.97^{* *}$ & $33.37^{* *}$ & -4 \\
\hline 15 & 19.25 & 1.01 & $8.36^{* *}$ & 0.01 & 11.14 & $25.81^{* *}$ & $28.85^{* *}$ & -5 \\
\hline
\end{tabular}

Bold cells indicate to the stable genotypes

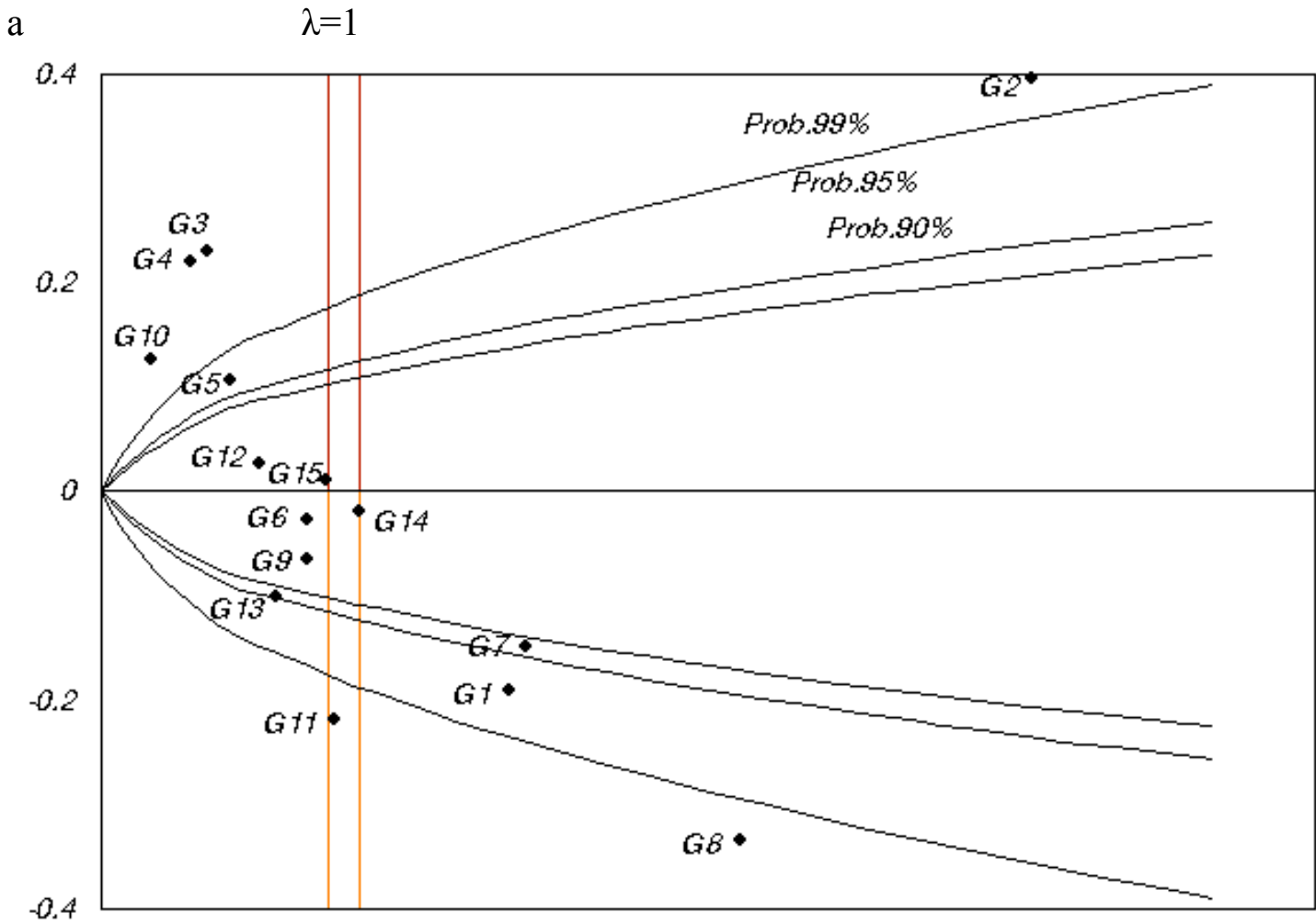

$\lambda$

Fig. (5): Distribution of stability statistics for seed weight/ plant

Data of yield stability $\left(\mathrm{Ys}_{i}\right)$ calculated as outlined by Kang and Magari (1995) presented in Table (8) showed that seven out of 15 genotypes had values of $\mathrm{Ys}_{i}$ greater than the mean $\mathrm{Ys}_{i}$ indicating stability of high performance for seed weight/ plant. On the other hand, eight genotypes were considered unstable seed weight/plant where their values of $\mathrm{Ys}_{\mathrm{i}}$ were less than the mean $\mathrm{Ys}_{i}$.

\subsection{Seed yield (ardab/fed)}

The results of the four stability methods regarding seed yield (ardab/fed.) are shown in Table (9). Sesame genotypes significantly affected seed yield (ardab/fed.). Genotype No. 
10 gave the highest value for this trait recording $4.32 \mathrm{ardab} / \mathrm{fed}$. Genotype No. 2 ranked the second (3.93 ardab/fed.) followed by Genotype No.1 (3.91 ardab/fed.), 5 (3.84 ardab /fed.) and 4 (3.64 ardab /fed.).The lowest seed yield (ardab/fed.) was obtained by genotypes No. 9 (2.31 ardab/fed.) and No.11 (2.42 ardab/fed.).The value of regression coefficient did not significantly differ from unity $(b=1)$ for the studied genotypes except for genotypes No. 1, 2, 3, 8, 9 and 11.Concerning the values of deviation from regression $\mathrm{S}^{2} \mathrm{~d}$, three genotypes were not significantly different from zero.
Genotypes No. 10, 2, 1, 5and 4 had seed yield greater than the mean of all genotypes. It was observed from the results that genotypes No. 4, 5 and 10 were phenotypically stable for seed yield where they met assumptions of Eberhart and Russell (1966) for stable genotypes.

The estimates of genotypic stability parameters and means of all genotypes for seed yield (ardab/fed.) are presented in Table (9). Fig. (6) illustrates the $\alpha$ and $\lambda$ distributions of fifteen genotypes. There are only three genotypes (G12, G13 and G14) located in the average stable area. The identified genotypes may be used as a

Table (9): Mean performance of seed yield (ard./fed) and phenotypic, genotypic, Shukla's and Kang and Magari stability measurements for fifteen sesame genotypes over 12 environments.

\begin{tabular}{|c|c|c|c|c|c|c|c|c|}
\hline \multirow{2}{*}{ Genotypes } & \multirow{2}{*}{ Mean } & \multicolumn{2}{|c|}{ Phenotypic stability } & \multicolumn{2}{|c|}{ GenotypicStability } & \multicolumn{2}{|c|}{ Shukla sstability } & \multirow{2}{*}{$\begin{array}{c}\text { Kang\&Magari stability } \\
\mathrm{Ys}_{i}\end{array}$} \\
\hline & & $\mathbf{b}_{\mathbf{i}}$ & $\mathbf{S}^{2} \mathbf{d}_{\mathrm{i}}$ & $\boldsymbol{\alpha}_{\mathrm{i}}$ & $\lambda_{\mathbf{i}}$ & Sigma square & S-square & \\
\hline 1 & 3.91 & $0.70 *$ & $0.507 * *$ & -0.32 & 39.67 & $1.80 * *$ & $1.68 * *$ & +8 \\
\hline 2 & 3.93 & $1.56^{*}$ & $1.228 * *$ & 0.59 & 94.26 & $4.77 * *$ & $4.18 * *$ & +9 \\
\hline 3 & 3.63 & $1.25 *$ & $0.164 * *$ & 0.26 & 13.38 & $0.62 * *$ & $0.49 * *$ & +5 \\
\hline 4 & 3.64 & 1.19 & 0.14 & 0.21 & 11.66 & $0.48 * *$ & $0.41 * *$ & +6 \\
\hline 5 & 3.84 & 1.20 & 0.11 & 0.21 & 9.47 & $0.40 * *$ & $0.31 * *$ & +7 \\
\hline 6 & 3.53 & 1.08 & $0.34 * *$ & 0.09 & 27.12 & $1.00 * *$ & $1.10 * *$ & +3 \\
\hline 7 & 2.93 & 0.86 & $0.51 * *$ & -0.15 & 40.34 & $1.59 * *$ & $1.69 * *$ & -7 \\
\hline 8 & 2.68 & $0.43 *$ & $1.01 * *$ & -0.61 & 77.68 & $4.15^{* * *}$ & $3.44 * *$ & -8 \\
\hline 9 & 2.31 & $0.76^{*}$ & $0.39 * *$ & -0.25 & 30.63 & $1.31 * *$ & $1.27 * *$ & -10 \\
\hline 10 & 4.32 & 1.21 & 0.07 & 0.22 & 5.83 & $0.26 * *$ & $0.15^{* *}$ & +10 \\
\hline 11 & 2.42 & $0.64 *$ & $0.37 * *$ & -0.38 & 28.93 & $1.48 * *$ & $1.20 * *$ & -9 \\
\hline 12 & 3.47 & 1.10 & $1.20 * *$ & 0.10 & 93.75 & $3.73 * *$ & $4.09 * *$ & +2 \\
\hline 13 & 3.14 & 1.04 & $0.25 * *$ & 0.04 & 20.15 & $0.70^{* * *}$ & $0.78 * *$ & -6 \\
\hline 14 & 3.46 & 1.11 & $0.34^{* *}$ & 0.12 & 27.00 & $1.02 * *$ & $1.09 * *$ & 0 \\
\hline 15 & 3.26 & 0.88 & $0.48 * *$ & -0.13 & 38.15 & $1.48 * *$ & $1.59 * *$ & -4 \\
\hline Grand mean & 3.36 & 1.0 & & & & & & 0.4 \\
\hline
\end{tabular}

Bold cells indicate to the stable genotypes

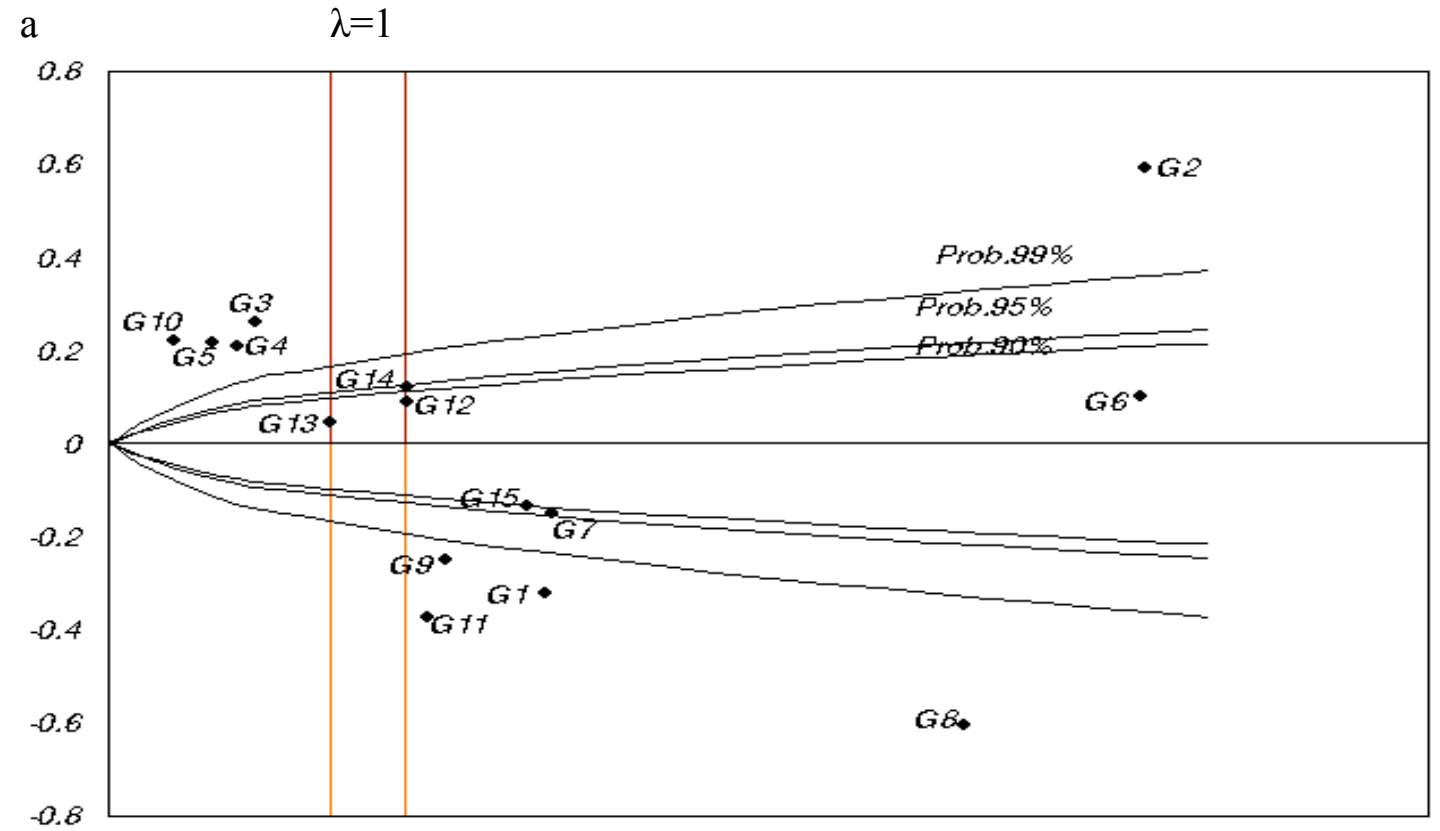

Fig. (6): Distribution of stability statistics for Seed sesame yield (ard/fed) 
source of genetic variability for sesame improvement program in the future as discussed by Adebisi and Ajala (2006), Adebisi (2010), Suvama et al. (2011) and Sedeck et al., (2014 b).

Concerning stability variance method of Shukla's (1972), the results in Table (9) showed that all genotypes were judged to be unstable, where their values of both $\sigma^{2}$ and $S^{2}$ were significant.

Data of yield stability $\left(\mathrm{Ys}_{i}\right)$ calculated as by outlined by Kang and Magari (1995) presented in Table (9) showed that eight genotypes out of 15 had values of $\mathrm{Ys}_{i}$ greater than the mean $\mathrm{Ys}_{i}$, indicating stability of high performance for seed yield. On the other hand, seven genotypes were declared unstable seed yield where their values of $\mathrm{Ys}_{i}$ were less than the mean $\mathrm{Ys}_{i}$.

\section{REFERENCES}

Adebisi M.A. and Ajala M.O. (2006). Performance and stability of seed yield in rain-fed sesame genotypes as influenced by plant population density. Tropical Agric. (Trinidad), 83 (2): 47-53.

Adebisi M. A. (2010). Stability AnalYSi s of seed germination and field emergence, performance of tropical rain-fed sesame genotypes. Nature and Science, 8 (2):1114.

Adebisi M.A., Ajala M.O. and Kehinde T. O. (2010). Seed production environment and potential, seed longevity of rain- fed sesame (Sesamum indicunm L.) genotypes. Research Journal of Seed Science, 4(3):166-173.

Eagles H.A. and Fery K.J. (1977). Repeatability of the stability-variance parameter in oats. Crop Sci., 17:253-256.

Eberhart S.A. and Russell W.A. (1966). Stability parameter for comparing varieties. Crop Sci., 16: 36-40.

El-Nakhlawy F.S. and Mohamed A.S. (2009). Response of seed yield, yield components and oil content to the sesame cultivar and nitrogen fertilizer rate diversity. Electronic J.Environ., Agric. and Food Chem. (EJEAFChe), 8 (4): 287-293.

Gebeyahu S. and Assefa H. (2003). Genotype x environment interaction and stability of seed yield in navy bean genotypes. Afr. Crop Sci. J., 11 (1):1-7.

Gomez K.A. and Gomez A.A. (1984). Statistical procedures for agricultural research $2^{\text {nd }} \mathrm{ed}$,
John Wiley and spons, New York, USA.

Kang M.S. and Miller J.D. (1984).Genotype x environment interaction for cane and sugar yield and their implications in sugarcane breeding. Crop Sci., 24: 435440.

Kang M. S. and Magari R. (1995). Stable: A basic program for calculating stability and yield-stability statistics. Agron.J., 87 (2): 276-277.

Kumaresani D. and Nadarajan N. (2005). Stability analysis for yield and its components in sesame (Sesamum indicumL.). Indian J. Agric. Res., 39(1): $60-63$.

Kumar S.T., Velusami P.A., Balamurugan R., Eswaran R. and Thangavelu P. (2008). GxE interaction and stability of sesame (Sesamum indicunmL.) genotypes over environments. Adv. in Plant Sci., 21(2):617-619.

Kumar T.S. and Kumar C. S. (2004). Stability of sesame (Sesamum indicum L.) varieties under different population densities, Sesame and safflower Newslett., 19:2631.

Sarwar G., Hussain A. and Akram M. (2010). Performance of newly developed mutants of sesame (Sesamum indicum L.).J. Agri. Res. 48(4): 445-455

Sedeck F. Sh., Teilep W.M.A.K. and Ali T.H. (2014 a). Genotype x environment inter action and path coefficient in sesame, Egypt. J. Plant Breed. 18(1): 95-104 (2014).

Sedeck F. Sh., Mahmoud M.W.Sh. and Shrayi R.E.A. (2014 b). Mean performance and stability of sesame genotypes under six different environments. Proc. of the Fifth Field Crops Conference, 18-20 Nov. 2014 Giza, Egypt 322-339.

Shukla G.K. (1972). Some statistical aspects of partitioning genotype-environment components of variability. Heredity, 29: 237-245.

Suvama M. H., Nehru S. D. and Manjunath A. (2011). Stability analysis of sesame varieties during early Kharif. Indian J. Agric. Res., 45(3):44- 48.

Tai G.C.C.(1971). Genotypic stability analysis and its application to potato regional trials. Crop Sci., 11:184-190. 


\section{إحصاءات الثبات لبعض التراكيب الوراثية من السمسم \\ فنجرى شحات صديق - سحر عبد العزيز فرج*}
قسم بحوث المحاصيل الزيتيةـ معهد بحوث المحاصيل الحقلية ـ ـ * المعمل المركزي لبحوث التصميم و التحليل

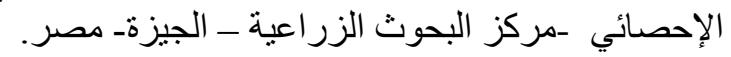

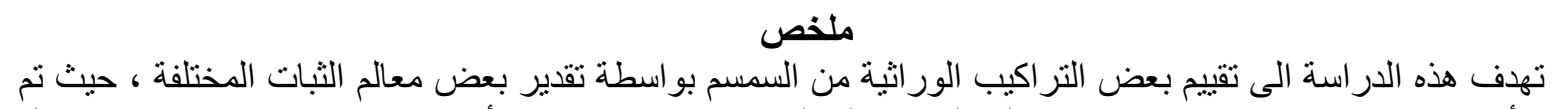

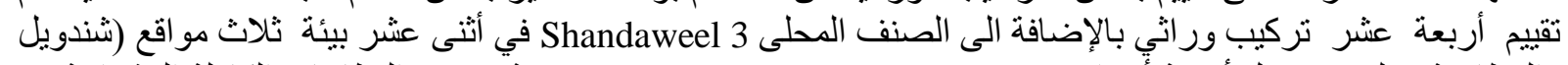

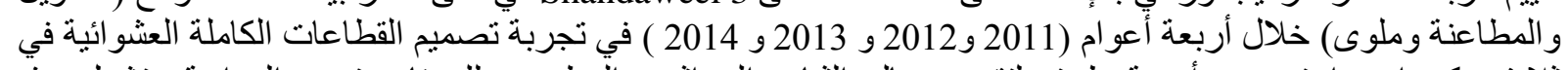

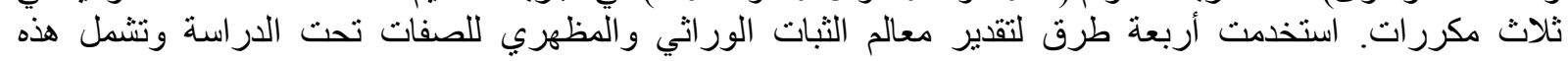

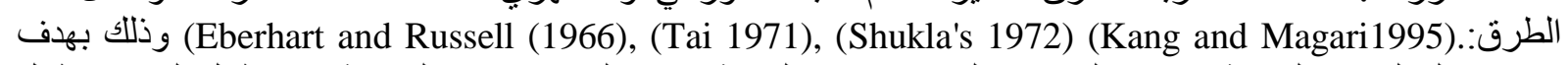

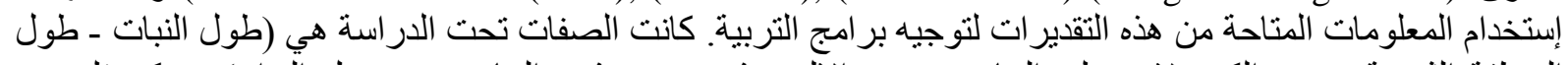

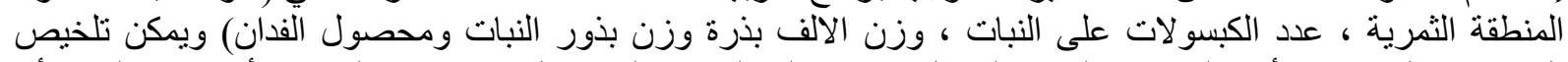

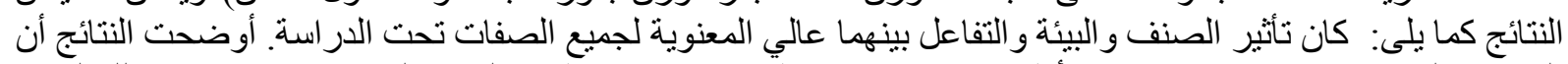

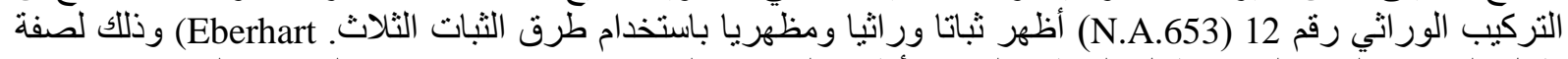

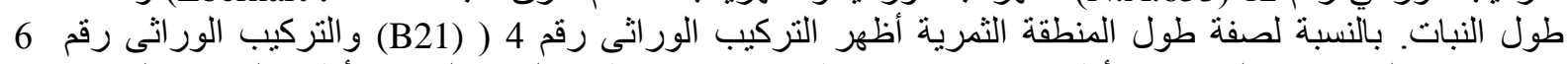

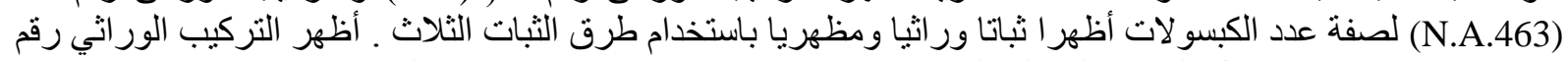

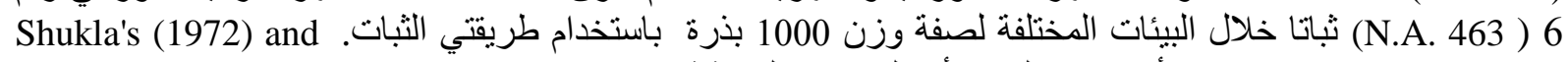
Kang and Magari (1995)

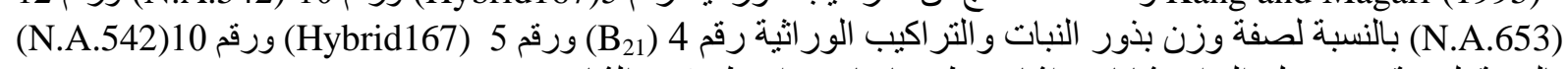

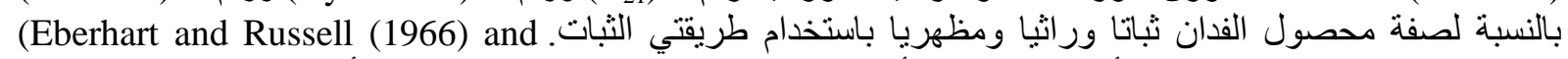

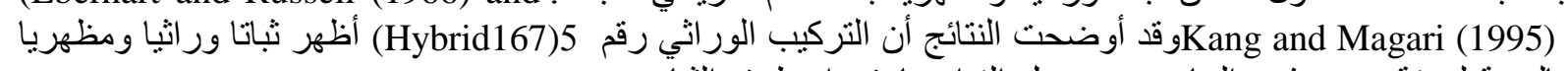
بالنسبة لصفة وزن بذور النبات ومحصول الفدان باستخدام طرق الثبات. (Eberhart and Russell (1966) and Kang and Magari (1995) و عليه ينصح باستعماله في بر امج التربية كأصل ور اثي حيث يتنتع بقدرة الثبات المرتفعة.

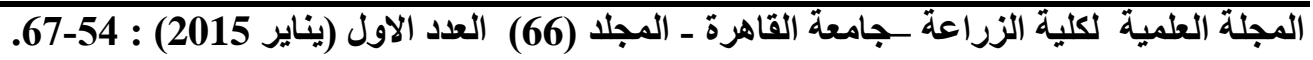

